\title{
Juvenile Criminal Behavior and Peers' Influences: A Comparative Study in the Brazilian Context*
}

\section{Conducta delictiva en la adolescencia e influencia de sus pares: un estudio comparativo en el contexto brasileño}

Recibido: noviembre 5 de 2011 | Revisado: febrero 10 de 2012 | Aceptado: marzo 10 de 2012

\author{
Marina REZENDE BAZON** \\ RUTH EsTEVÃO *** \\ Univeridade de São Paulo, Brasil
}

SICI: 2011-2277(201212)11:4<1157:JCBAPI>2.0.CO;2-7

Para citar este artículo: Rezende, M. \& Estevão, R. (2012). Juvenile Criminal Behavior and Peers' Influences: A Comparative Study in the Brazilian Context. Universitas Psychologia, 11(4), 1157-1166.

* This research was supported by Grupo de Estudios e Pesquisa em Desenvolvimiento e Intervenção Psicossocial (GEPDIP).

** Departamento de Psicologia. Facultade de Filosofia, Ciências e Letras de Ribeirão Preto. Univeridade de São Paulo. Av. Bandeirantes, 3900. 14040-901. Ribeirão Preto, São Paulo, Brasil.E-mail: mbazon@ ffclrp.usp.br. ResearcherID: G-8677-2012

*** Departamento de Psicología, Universidade de São Paulo, Brasil. E-mail: rues@uol.com.br. ResearcherID: H-1572-2012

\begin{abstract}
A B S T R A C T
This study investigates aspects of living with peers in adolescent offenders in the Brazilian context based on the social and personal control behavior theory developed by Marc Le Blanc and his colleagues. Both comparative and quantitative approaches were used to study two groups: Delinquents/adjudicated and control. A questionnaire developed by Le Blanc and adapted to the reality of the study was applied to 75 participants. A significant level of 0.05 was adopted and the data analysis showed that delinquents developed poor relationships suggesting an experience of greater socio-emotional isolation. This refers to the problematic experience in one of the major developmental tasks of this period. Further studies should be developed to analyze the interactions between the coexisting aspects in the family, at school and with peers.

Key words authors

Adolescents, Delinquents' Peers, Personal and Social Control, Behavior Theory. Key words plus

Social Psyhcology, Quantitative Research, Brazil.
\end{abstract}

\section{RESUMEN}

El presente estudio indaga la relación entre adolescentes infractores y sus pares dentro del contexto brasileño, basándose en la teoría de la regulación social y personal de la conducta, desarrollada por Marc Le Blanc y sus colegas. Se aplicó un cuestionario desarrollado por Le Blanc, y adaptado a la realidad del estudio, a 75 participantes. Se consideró un nivel de significación de 0.05 y el análisis señala que los delincuentes desarrollan relaciones interpersonales pobres, experimentando un elevado aislamiento socioemocional, que se constituye en una de las experiencias más problemáticas dentro de las tareas de desarrollo en esta etapa. Así mismo, estudios futuros deberían analizar la interacción entre aspectos contextuales en la familia, escuela y con los pares.

Palabras clave autores

Adolescentes, delincuentes, pares, teoría del control de la conducta personal y social.

Palabras clave descriptores

Psicología social, investigación cuantitativa, Brasil. 
In many different countries, criminal offenses reach their peak in adolescence. This can be better explained by the impact that social influences have on this particular stage of life, especially by peers that seem to encourage unlawful behavior. In adolescence, there is great variability of life experiences, creating greater openness to influences from social groups other than the family (Farrington, 2002). In this situation, the relationship of the adolescents with their peers is emphasized as a means of protection or risk (Dell'Aglio, Benetti, Deretti, D'Inácio \& Leon, 2005; Pereira \& Sudbrack, 2008). According to Haynie and Osgood (2005), at this stage, more than in any other, they spend a lot of time with friends and consider them very important, which justifies the investment in research on the association between peers and teenage behavior.

As a protective factor, it is known that the fact of establishing and maintaining relationships with peers in adolescence, as well as responding to an intrinsic need of this developmental phase, the balance between autonomy and mental capacity to share intimacy (Giordano, 2003; Marcus, 1996; Selman, 1989), can promote the development of relevant social skills for the individual's psychosocial adjustment, such as communication and resolution of interpersonal conflicts (Branco \& Wagner, 2009; Costa \& Assis, 2006; Dell'Aglio et al., 2005). With regard to the risks, one of the most consistent scientific data, according to the review studies, is that there is a strong association between the juvenile delinquents' behavior and their peers, that is, adolescents who report having delinquent friends are more at risk to develop problematic behavior, than the ones who say they have few or no delinquent friends (Haynie \& Osgood, 2005; Le Blanc \& Morizot, 2000). This emphasizes the importance of the type of peer with whom they are preferentially associated.

However, some investigations have also shown that a small group of friends is necessarily connected to a larger network of peers, generally heterogeneous, i.e. it comprises others with and without problematic behavior (Haynie, 2001, 2002). The composition of the network (the proportion of delinquent friends in relation to non-delinquent), and its structure (density and position occupied by the teenager in the network), are the features that could moderate the strength of the association between the adolescents' behavior and their closest friends (Haynie \& Osgood, 2005).

According to Le Blanc (2003), it should also be considered that the association with deviant peers is normally done in two ways: Having friends who commit criminal acts and join a more or less organized group of delinquents (a gang.) The degree of involvement with criminality, particularly with the seriousness and variety of them, tends to be higher for teenagers who claim to be members of a gang (Thornberry, Krohn, Lizotte \& Chard-Wierschem, 1993; Thornberry, Krohn, Lizotte, Smith \& Tobin, 2003).

Another of the aspects considered by some studies is the quality of the relationships between the peers, with contradictory reports focusing specifically on the relationship between delinquents (Le Blanc \& Morizot, 2000; Marcus, 1996). There are indications, on one hand, that shows an alteration in the level of involvement of a teenager with criminal acts that correlates significantly with a similar alteration in the levels of intimacy with their friends. This suggests that the influence that juvenile delinquents have on each other depends on the level of attachment between them.

On the other hand, evidence shows that the relationships between them are significantly poor in terms of attachment, and permeated by more conflicts that are difficult to solve due to the deficits in social skills, therefore, providing less stability in such relationships.

Regardless of the quality of the relationship between teenagers, a key issue emerges: Does the affiliation with disruptive peers precede the incidence of such conduct in the adolescents, or does this conduct favor their affiliation with delinquent peers? (Farrington, 2002; Le Blanc \& Morizot, 2000). Three major theoretical perspectives are proposed to explain this: a) Individual characteristics that emphasizes the selection process, under which people with similar interests and behaviors (also similar in the socio-demographic aspect) tend to associate ("the similar 
ones attract each other"); b) Social learning, which emphasizes the process of socialization by the group, whereby a teenager learns values, attitudes and behaviors; c) Interaction's perspective, which emphasizes the process of facilitating delinquent behavior in which the association with the deviant peers would play the moderate role as it aggravates a pre-existing problem, therefore merging both selection and socialization perspectives (Giordano, 2003; Haynie \& Osgood, 2005; Le Blanc \& Morizot, 2000). Data from current research findings, in fact, reveal that the selection and socialization processes are not of exclusive nature. Two-way influence effects are more properly observed between teenagers' conduct and their peer behavior, which corroborates the interaction explanation (Baerveldt, Knecht, Raub, Snijders \& Steglich, 2010; Giordano, 2003; Haynie \& Osgood, 2005).

Opportunity is aggregated to this perspective, which is related to the theory of social ecology (Haynie \& Osgood, 2005). By this approach, the relationships with peers are also important as they shape the day to day life in terms of spatial and temporal patterns by structuring the opportunities for learning and emitting different behaviors. The evidence shows that the risks for delinquent behavior will be higher if the routine outlined by the peer group activities is comprised in disruptive ones, and are developed without any authority supervision (Le Blanc, 2003; Le Blanc \& Morizot, 2000).

The romantic relationships between peers (love relationships), including the relationships with the opposite sex, should be observed. According to Giordano (2003), although there aren't too many specific investigations, it is known that the interest in the opposite sex is a structuring factor during adolescence. For the male adolescent, the fact that he has a girlfriend generally produces a positive social influence that will depend on its quality. However, for teenagers of both sexes, the early and intense engagement in romantic relationships normally indicates their need for identity and status, as they are not able to find those in any other sources. This could reveal some development problems.
In addition, we should also consider that the early engagement in relationships with the opposite sex is often related to the association with deviant peers (Friedlander, Connolly, Pepler \& Craig, 2007).

The current study presents the results of a research done in Brazil, specifically in an inner city in the State of São Paulo, aiming to investigate the influence of peers on juvenile delinquency in order to contribute with scientific knowledge in the topic. For its development, the theoreticalmethodological approach used was the personal and social control behavior theory in adolescence developed by one of its main author, Marc Le Blanc (1996, 1997, 2003). Briefly, the main propositions of this theory state that the regulation (control) of conduct occurs through reciprocal interactions between personal mechanisms (related to the level of psychological development and the adolescent's personality), and social mechanisms (bonds to different institutions and their members, particularly those of family, school and peers; constraints exerted by social institutions, i.e., specific social pressures that contribute to the behavior in conformity with the rules; degree of exposure to different influences and opportunities, according to conventional standards/legal or not).

Control/regulation would not happen only by general mechanics, transcending the institutions responsible for the socialization of adolescents, but particularly in each one of them. As for peer regulation, it is first claimed that to live among teenagers, it is necessary to evaluate five dimensions: a) The context of relationships with peers; b) The engagement; c) The attachment; d) Investment of time with them; and e) Affiliation. According to the theory, the network of peers, its size, and approval of friends by parents constitute the context in which the attachment, investment and engagement can or cannot flourish, comprising the social bond. The commitment (built on the sense of loyalty, as well as on efforts to exert the leadership role in the group) is an attitude that has greater values linked to them than the ones conveyed by parents/guardians and other authority figures. 
Attachment (built on mutual communication and trust) is a source of engagement. These two dimensions, attachment and engagement allow feedback and compete for more investment in the relationship with peers (time spent on activities shared by them).

The impact of the existing dynamics between these dimensions in conduct can be mediated by the nature of affiliations (the type of peers, which refers to the investigation of models to which they are exposed, including their connection with the peers of the opposite sex, with peers and/or adults with illegal/criminal conduct and with conventional adults), as well as to the peer pressure on their behavior, conventional or not, which refers to the constraints that the group can exert over the adolescent. If the affiliations were overwhelmingly linked to the conventional figures, the control at this level would provide the adolescent with a conventional behavior; conversely, if the affiliations were overwhelmingly linked to anti-social figures, the control would lead the adolescent to offensive behavior.

From this perspective, this study sought to know aspects of the relationship between adolescent offenders with their peers in Brazil by analyzing the components mentioned above. Two distinct groups participated in the study: One with adjudicated teenagers due to offensive acts, and the other without this profile. The specific objective was to verify if the groups differed in terms of attachment, engagement, and investment in relation to peers as well as to their affiliations to examine the dimensions that are associated with the adolescent offenders.

\section{Method}

\section{Participants}

The sample comprised 75 male adolescents, age ranged from 13 to 18: 32 juvenile delinquents, average age 16.56 years $(S D=0.22)$, recruited as part of a Probation program, and 43 non-delinquents, average age 15.63 years $(S D=0.14)$, recruited as part of community program for adolescents.

\section{Materials and Procedure}

For data collection, we used a Portuguese version of a structured questionnaire around the theme "peers" that was developed under the perspective of the personal and social control behavior theory by Marc Le Blanc (1996). It is important to emphasize that this instrument is relevant to children and adolescents with age ranging from 10 to 20 years, of both sexes, and from any ethnic group. It has already been validated and adapted for use in some countries besides Canada: Spain (Le Blanc, Lopez, Espuny, Fortuno \& Kazemian, 2004); France (Brandibas, Fourasté, Favard \& Le Blanc, 1998), and Algeria in Northern Africa (Bergheul, 2003).

In the present study, with the author's authorization (Marc Le Blanc), the Peer Questionnaire was adapted semantically to our context. It was translated and back translated and later tested with a sample of adolescents to analyze the appropriateness of the used terms. The questionnaire consists of 53 questions seeking information about: a) Context of relations with peers to evaluate the size of the peers' network and parental approval of friends; b) Bond to peers to evaluate: The "investment" of time with the peers investigated by questions on the number of hours devoted to activities with friends and on the number of hours talking with peers; "attachment to friends", investigated by questions on "communication" (referring to the possibility of asking for advice, talking with them about personal matters, other friends and their relationship with parents), on "exchange" (referring to the possibility of borrowing money from friends, on the "affective assimilation" (referring to the identification with friends), and on "confidence" in them and "engagement" in relation to peers, investigated by questions on "loyalty" (referring to the ability of adolescents to defend his friends in many situations), and on the "role that the teenager plays in his group" (checking whether he considers that he plays a leading role among friends) and "affiliation", evaluated by the exposure to Models and Constraints exerted by peers. With regard to Models, the questions refer to frequency and investment in "friends of the opposite sex" (including here the investigation 
TABLE 1

Synthesis of the Results Obtained by the Delinquents and Non Delinquents Groups and the Comparison between them

\begin{tabular}{|c|c|c|c|c|c|c|}
\hline & \multirow[b]{2}{*}{ Dimensions } & \multicolumn{2}{|c|}{$\begin{array}{l}\text { Adolescents } \\
\text { offenders }\end{array}$} & \multicolumn{2}{|c|}{$\begin{array}{l}\text { Adolescents } \\
\text { Non offenders }\end{array}$} & \multirow[b]{2}{*}{$p$} \\
\hline & & M & SD & M & $S D$ & \\
\hline \multirow{4}{*}{ Context } & Networks size & 32.16 & 5.25 & $70.69 *$ & 5.58 & 0.001 \\
\hline & a) Number of best female friends & 3.27 & & 6.83 & & \\
\hline & b) Number of best male friends & 3.37 & & 12.63 & & \\
\hline & Parents/guardians approval of friends & 2.91 & 0.22 & $3.84^{*}$ & 0.14 & 0.002 \\
\hline \multirow{12}{*}{ Bonds } & Investment & & & & & \\
\hline & a) Investment in relation to peers/friends & 6.69 & 0.51 & $8.93 *$ & 0.41 & 0.002 \\
\hline & Attachment & & & & & \\
\hline & Attachment to peers $(6-24)$ & 11.94 & 0.58 & $15.56^{*}$ & 0.41 & 0.001 \\
\hline & a) Communication & 7.91 & 0.46 & $11.19 *$ & 0.34 & 0.001 \\
\hline & b) Exchanges & 2.69 & 0.14 & 2.88 & 0.13 & 0.332 \\
\hline & c) Affective assimilation / identification & 1.34 & 0.12 & 1.49 & 0.10 & 0.257 \\
\hline & d) Confidence in friends $(1-4)$ & 3.15 & 0.17 & 3.58 & 0.11 & 0.076 \\
\hline & Engagement & & & & & \\
\hline & a) Loyalty to peers & 7.78 & 0.38 & $9.53 *$ & 0.31 & 0.001 \\
\hline & b) Role: leadership & 1.47 & 0.10 & $2.51^{*}$ & 0.13 & 0.001 \\
\hline & c) Investment of time in relation with the opposite sex & 8.78 & 0.76 & 8.28 & 0.88 & 0.987 \\
\hline \multirow{4}{*}{ Models } & Dating age : early involvement with the opposite sex & 11.44 & 0.71 & 10.49 & 0.91 & 0.428 \\
\hline & Exposure to deviant peers & 7.25 & 0.38 & 6.84 & 0.39 & 0.458 \\
\hline & To know criminal adults & 0.72 & 0.08 & $0.44 *$ & 0.08 & 0.041 \\
\hline & To have adult friends & 1.03 & 0.03 & 1.07 & 0.04 & 0.779 \\
\hline \multirow{2}{*}{ Constraints } & Peer pressure (fear of loosing friends) & 1.81 & 0.12 & $1.49 *$ & 0.11 & 0.05 \\
\hline & Resentful pressure to commit criminal acts & 1.34 & 0.08 & $0.72 *$ & 0.08 & 0.001 \\
\hline
\end{tabular}

$* p \leq 0.05$

Source: own work.

on investment in pairs of opposite sex and dating), and the behavior of people with whom they relate, adults and adolescents, investigating the possibility of having "friends arrested by the police" and meeting "adult criminals". With respect to the pressure exerted by peers (Constraints), we investigate the "fear of losing friends" for behaving very differently from them, and the resentful "pressure to commit criminal acts", meaning to have to commit them to keep their friends.

Collection of data with participants from both groups was performed individually, in a private room to ensure privacy, following the contexts of the programs where the participants were recruited. The questionnaire was applied orally. The questions and answer alternatives were read to them in order to standardize the collection. The answers given were included in the computerized program named MASPQ (Measuring Adolescent Social and Personal Adaptation) - version 2.0 for Windows (Copyright (C) Le Blanc, 2001) that provided the raw and standardized scores for each variable by participant. In this study, only raw scores were used. They were inserted in a worksheet properly prepared in Microsoft EXCEL for statistical purposes. In order to ascertain whether the differences between the 
means obtained by the two groups were significant for each variable (dimensions), the Student's $t$ test was applied (when data showed a normal distribution) or the Mann-Whitney Rank Sum Test (when the distribution of data was not normal). In all analyses, we adopted an alpha level of 0.05 .

\section{Results}

The results are summarized in Table 1 . It shows the average scores obtained for each group, in the five dimensions evaluated, as well as the statistical comparison of the groups. The results show that the adolescent offenders differ significantly from the non-offenders in 10 out of 17 dimensions evaluated $(p \leq 0.05)$.

In the Context of relations with peers, the differences between the two groups would take place at the "networks size" ( $p \leq 0.001)$ as well in the "degree of approval of colleagues/friends by parents/guardians" $(p \leq 0.002)$. The offenders reported to belong to smaller networks and to have less approval of friends by parents than the non-offenders. Focusing on the peer Bond, we founded differences in five of eight variables: "investment in relation to peers/friends" ( $p \leq 0.002)$; "attachment" ( $p \leq 0.001)$; "communication" ( $p \leq 0.001)$; and, concerning engagement "loyalty to peers" ( $p \leq 0.001)$ and "leadership role" ( $p \leq 0.001)$. Generally, it indicates that the bonds that they hold in relations with peers are weaker. With respect to Models, the difference between the two groups is only the fact that the offenders "know more criminal adults" ( $p \leq 0.041)$. For the last dimension, the Constraints, the differences are in the both variables, "fear of loosing friends" $(p \leq 0.05)$ and "pressure to commit criminal acts" ( $p \leq 0.001$.) This shows that they feel more pressure in the relationship with their peers.

\section{Discussion}

The investigated adolescents are different in shifting aspects regarding the peers' relationship. The Context of these relations for the groups is different with respect to the "networks size": The offenders reported to belong to smaller networks than the non-offenders. Although the literature shows that there is some variation in the network size to which the adolescent belongs, it may refer to a large group of colleagues or a small group of close friends (Ennett \& Bauman, 2000). Le Blanc (2003) argues that juvenile delinquents generally mention a larger number of acquaintances than the non-offenders, which contradicts the findings presented here. The difference found may be explained by the teenagers' interpretation of the question "how many people of your age do you know personally?", to which, perhaps, in both groups, they would refer to the number of people they actually know and not consider the term "personally", which would require the respondents to be restricted to "closest ones". Meaning that it makes sense that the non-offenders have referred to know, on average, 70 other teens, as they attend educational institutions (schools and community programs) where they share their daily life with several other people. On the other hand, the offenders (until the judicial measure is applied) were characterized by the exclusion of those institutions, having referred to know, on average, only 32 youngsters of their own age (Branco \& Wagner, 2009). In this perspective, the difference between the groups persists regarding the number of close friends mentioned, however, according to the literature. The non-offenders reported having more friends than the offenders, most of them of the same sex. Therefore, the result reflects greater difficulty for the offenders to establish and maintain close relationships (Haynie \& Osgood, 2005; Le Blanc, 1996; Marcus, 1996).

Regarding the "level approval of those friends by parents", according to the teenagers' view, the results indicate that there seems to be less discrepancy between the non offenders' choices of friends and the opinions of the responsible ones. The data indicates a higher probability of conflicts between parents and teenagers in the offenders' group. According to the literature, these conflicts may provide opportunities for the adolescents to become more susceptible to the influence of peers. This may occur to increase the challenge of supervising the youngsters, and eventually to destabilize the more harsh (coercive) disciplinary practices (Le Blanc, 1996; Le Blanc \& Janosz, 2002). 
Now focusing on the peer Bond, "investment" indicates that the time spent with friends is significantly more in the non-offenders group, consistent to the strongest "attachment" experienced by these, which is based on greater/better "communication". In this control group, there was also greater "engagement" in relation to peers, based on greater "loyalty" and commitment with respect to the exercise of "leadership" among them. Thus, it can be considered the offenders bond with their peers would be minor, due to less time invested in the relationship, consistent with the existence of less attachment and less engagement. These results confirm the literature that shows that the juvenile delinquents maintain a bad quality of friendship (Deater-Deckard, 2001; Marcus, 1996). The results found corroborate central part of the social bond paradigm (Baerveldt et al., 2010; Le Blanc, 1997), whereby it is assumed that youngsters with behavioral problems lack close interpersonal relationships (Haynie, 2001).

It is of major importance in terms of "attachment", to mention that trust and identification levels, as well as the exchange behavior with peers, was similar in both groups. This emphasizes the role of "communication" in establishing peer attachment, denoting that the juvenile delinquents may have deficits in social skills, and experience difficulties to share their thoughts and feelings with others (Selman, 1989).

As for the exposure of adolescents to Models, with regard to "affiliations", the groups did not differ significantly with regard to the fact that they have adult friends outside the family context. What differentiates offenders from non-offenders is the fact that the first ones know, on average, more "criminal adults". This data indicates a worrying situation, which is the direct contact of such adolescents with adult crime. So, juvenile delinquents coexist with criminal adults, which reveal the possibility of having a criminal career, "live through crime". Furthermore, depending on the degree of closeness between them, those adults may be playing an active role regarding the adolescents' socialization (values, beliefs, attitudes and behaviors that can be aligned with criminal engagement).
The both groups are equivalent to the exposure to other adolescents showing a divergent behavior (such as the consumption of alcohol and other drugs and unlawful acts). It is known that the network of relationships of most teenagers is heterogeneous, i.e., with peers that present or not a divergent behavior. However, according to what has been proposed in the literature, it was expected that the number and the proximity of peers with deviant behavior in the juvenile delinquents network would be significantly higher, but it didn't happen. Such information, taken separately, attenuates the strength of the hypothesis on the distinctive association between the offenders peers investigated in this study.

In addition, delinquents and non-delinquents were not distinguished considering the interest and investment of time in the "relationship with peers of the opposite sex", emphasizing that the average age to start dating, reported by young people from both groups as being fairly low, brings back to childhood (11.44 and 10.49 years old, respectively). Le Blanc (1996) draws attention to the fact that early interest in romantic relationships can be a risk factor as it distracts the youngsters from their main activities which are studying or going to school, and it would increase the risk for disruptive activities.

Finally, in the Constraints, significant differences were observed between groups not only for "fear of losing friends" because they have committed a criminal act, but also for the "pressure felt by the peers for practicing such acts". In both cases, the delinquents scored high, indicating a contradictory experience for this group, i.e., such adolescents reveal that they feel isolated from their peers because they are involved with criminal offences and, at the same time, they feel forced to engage in unlawful acts. Certainly, such pressure can come from different sources, as the youngsters belong to heterogeneous networks. However, such consideration does not solve the doubts concerning the influence that the peers with different behavior may have. The literature reveals that little is known about the quality of relationships between the delinquents and their non-delinquent peers, since most of the research work is basically carried out by studying the quality 
of the relationships among the offenders (Le Blanc, 1997), giving emphasis on the data that show that the quality relation between them is poor (Le Blanc \& Morizot, 2000; Marcus, 1996).

In the perspective of the Theory adopted, to understand the control nature of adolescents' behavior by their peers, it is necessary to understand the profile outlined by all the information obtained from the different evaluated dimensions (Le Blanc, 1996). Then, it can be said that the juvenile delinquents belong to networks with few peers (consisting of a smaller number of acquaintances) and therefore, a smaller number of friends (i.e., peers to relate more closely with). This network, formed by a few acquaintances and friends, does not necessarily present a higher proportion of adolescents with divergent conduct, which proves that the juvenile delinquents (the same way for the non-delinquents) interact equally with other delinquents and nondelinquents. This shows that the especially differentiated association between deviant peers does not happen. On the contrary, the delinquents are associated with all "types" of adolescents and identify themselves with them by exchanging objects/things based on trust (similarly to the non-delinquents). The specificity of this group lies in the fact that, despite the way the interactions is characterized, they would become less attached, mainly because the communication would flow less as the offenders would not talk so much with the others about personal issues and consequently would ask their friends for less advice. Furthermore, it is clear that the quality of the delinquents' bond with their peers is generally lower. It is also observed that they invest less time in their relationships and are less engaged with their peers as they demonstrate less loyalty to friends and do not do their best to play a prominent role in the peer group. In short, the juvenile delinquents would interact with the others delinquents and non-delinquents, but the bond with them would be frail due mainly to a lower share of intimacy, which reveals poor quality in their relations, in general, and also some difficulty in achieving developmental tasks that are typical in this group.

As for the group pressure, it could avoid the approximation of the adolescents offenders with their peers (delinquents or not), prevent communication, and consequently, broaden the emotional isolation. In that same direction, there is the delinquents' perception regarding the lower level of approval of friends by parents/guardians that can be one more element to make such relationship qualification difficult with their peers, as it can also restrict them from being closer. It must be emphasized that the outlined dynamics of juvenile delinquents with their peers happens in a context to which they are exposed - differentially - to adults with criminal behavior that could be role models for them, increasing the distance between the adolescents and their reference group.

These results support, in part, the results of Woodward, Fergusson and Horwood (2002), when they studied the effect the involvement of adolescents with deviant and non deviant partners and found that, in fact, the relationship with peers that present a disruptive behavior was associated with an increased risk of delinquency, but a similar risk was also associated with the fact the adolescents did not have partners, i.e., or were experiencing poor relationships with their peers. The withdrawal of the adolescent from social relationships with peers can indirectly serve to perpetuate external problems presented by limiting the quantity and quality of socialization amidst colleagues/friends who predominantly have a pro social behavior (DeaterDeckard, 2001). In the medium and long term, the deficits resulting mainly from the social skills - can increase the vulnerability of the youth to the influence of delinquent peers by increasing the risk of continuing the deviant conduct (Ngai, Cheung \& Ngai, 2007). Kaufmann, Wyman, Forbes-Jones and Barry (2007) argued that a pro social involvement moderates the positive association normally found between the affiliation with contradictory peers and deviant behavior.

Certainly, the relationship nature of the juvenile delinquents with their peers, by itself, is insufficient to explain the emergence and persistence of such conflicting behavior in adolescence. This aspect should be considered jointly with the relationship nature of adolescents in the family and at school. More complex and updated studies should be devel- 
oped on the relationship between the possible interactions experienced by the juvenile delinquents, concomitantly, in the family, at school and with different types of peers.

\section{References}

Baerveldt, C., Knecht, A., Raub, W., Snijders, T. A. B. \& Steglich, C. E. G. (2010). Friendship and delinquency: Selection and influence processes in early adolescence. Social Development, 19(3), 494-514. doi: 10.1111/j.1467-9507.2009.00564

Bergheul, S. (2003). Adaptation du MASPAQ à une population d'adolescents et de jeunes délinquants : le MASPAA [MASPAQ. Adaptation for a population of adolescents and young offenders: the MASPAA]. Thèse de Doctorat en Psychopathologie, Université de Toulouse le Mirail, Toulouse, France.

Branco, B. M. \& Wagner, A. (2009). Os adolescentes infratores e o empobrecimento da rede social quando do retorno à comunidade [The juvenile delinquents and the weakening of the social network when they return to the community]. Ciência \& Saúde Coletiva, 14(2), 557-566.

Brandibas, G., Fourasté, R., Favard, A.-M. \& Le Blanc, M. (1998, June). Proposition pour une méthodologie d'évaluation de la régulation des troubles $d u$ comportement de l'adolescent: validation française du MASPAQ (Mesures de l'Adaptation Sociale et personnelle pour les adolescents québécois) [Proposal for a methodology to assess the control of behavior disorders in adolescents: Validation of the french MASPAQ (measures of social and personal adjustment for Quebec adolescents)]. Paper presented at the XVI ${ }^{\circ}$ Colloque du GROFRED, Université de Genève, Faculté de Psychologie et des Sciences de l'Education, Genève, Suisse.

Costa, C. R. B. S. F. \& Assis, S. G. (2006). Fatores protetivos a adolescentes em conflito com Lei no contexto sócio-educativo [Protective factors for adolescents in conflict with law in the socioeducational context]. Psicologia $\mathfrak{E}$ Sociedade, 18(3), 74-81.

Deater-Deckard, K. (2001). Recent research examining the role of peer relationships in the development of psychopathology. Journal of Child Psychology and
Psychiatry and Allied Disciplines, 42(5), 565-579. doi:10.1017/S0021963001007272

Dell'Aglio, D. D., Benetti, S. P. C., Deretti, L., D’Inácio, D. B. \& Leon, J. S. (2005). Eventos estressores no desenvolvimento de meninas adolescentes cumprindo medidas sócio-educativas [Stressor events in the development of adolescent girls fulfilling social and educational measures]. Paidéia, 15(30), 119-129. doi: 10.1590/S0103-863X2005000100013

Ennett, S. T. \& Bauman, K. E. (2000). Adolescent social networks: Friendship cliques, social isolation, and drug use risk. In W. B. Hansen, S. M. Giles \& M. Fearnow-Kenney (Eds.), Improving prevention effectiveness (pp. 47-57). Greensboro, NC: Tanglewood Research.

Farrington, D. P. (2002). Fatores de risco para a violência juvenil [Risk factors for youth violence]. In E. Debarbieux \& C. Blaya (Eds.), Violência nas escolas e políticas públicas (pp. 25-57). Brasilia: UNESCO.

Friedlander, L. J., Connolly, J. A., Pepler, D. J. \& Craig, W. M. (2007). Biological, familiar, and peer influences on dating in early adolescence. Archives of Sexual Behavior, 36(6), 821-830. doi: 10.1007/ s10508-006-9130-7

Giordano, P. C. (2003). Relationships in adolescence. Annual Review of Sociology, 29(1), 257-281. doi: 10.1146/annurev.soc.29.010202.100047

Haynie, D. L. (2001). Delinquent peers revisited: Does network structure matter? American Journal of Sociology, 106(4), 1013-1057. doi: 10.1086/320298

Haynie, D. L. (2002). Friendship networks and delinquency: The relative nature of peer delinquency. Journal of Quantitative Criminology, 18(2), 99-134. doi: 10.1023/A:1015227414929

Haynie, D. L. \& Osgood, D. W. (2005). Reconsidering peers and delinquency: How do peers matter? Social Forces, 84(2), 1109-1130. doi: 10.1353/ sof.2006.0018

Kaufmann, D. R., Wyman, P. E. A., Forbes-Jones, E. L. \& Barry, J. (2007). Prosocial involvement and antisocial peer affiliations as predictors of behavior problems in urban adolescents: Main effects and moderating effects. Journal of Community Psychology, 35(4), 417-434. doi:10.1002/jcop.20156

Le Blanc, M. (1996). MASPAQ: mesures de l'adaptation sociale et personnelle pour les adolescents québécois 
[Measures of personal and social adjustment for Quebec adolescents] (3ème. ed.). Montréal: Université de Montréal, École de Psycho-Education, Groupe de Recherche sur les Adolescents en Difficulté.

Le Blanc, M. (1997). A generic control theory of the criminal phenomenon: The structural and dynamic statements of an integrative multilayered control theory. In T. P. Thonberry (Ed.), Developmental theories of crime and delinquency: Advances in theoretical criminology (pp. 215-285). New Brunswick: Transaction Publishers.

Le Blanc, M. (2001). MASPAQ: Mesures de l'adaptation sociale et personnelle pour les adolescents québécois: manuel et guide d'utilisation [Measures of personal and social adjustment for Quebec adolescents: Manual and user guide], Version 2.0 (4th. ed.). Montreal: Université de Montréal, École de Psycho-Education, Groupe de Recherche sur les Adolescents en Difficulté.

Le Blanc, M. (2003). La conduite délictueuse des adolescents et quelques facteurs explicatifs [Delinquent behavior of adolescents and some explanatory factors]. In M. Le Blanc, M. Ouimet \& D. Szabo (Eds.), Traité de criminologie empirique (pp. $367-$ 420). Montréal: Les Presses de l'Université de Montréal.

Le Blanc, M. \& Janosz, M. (2002). Regulação familiar da conduta delinquente em adolescentes [Family control of delinquent behavior in adolescents]. In A. Castro (Ed.), Comportamento anti-social e família: uma abordagem científica (pp. 37-92). Coimbra: Edições Almedina.

Le Blanc, M., Lopez, M. T., Espuny, D. F., Fortuno, R. C. \& Kazemian, L. (2004). Medidas de adaptación social y personal para adolescentes españoles. Análisis de su coherencia interna, fiabilidad y validez. In F. Pérez (Ed.), Serta in memoriam Alexandri Barrata (pp. 465-488). Salamanca: Ediciones Universidad de Salamanca.

Le Blanc, M. \& Morizot, J. (2000). Le rôle des pairs dans l'émergence et le développement de la conduite délinquante: une recension critique des écrits [The Role of Peers in the Emergence and Development of Delinquent Behavior: A Critical Review of the Literature]. Revue Canadienne de Psycho-Education, 29(1), 87-117.

Marcus, R. F. (1996). The friendships of delinquents. Adolescence, 31(121), 145-158.

Ngai, N. P., Cheung, C. K. \& Ngai, S. S. (2007). Cognitive and social influences on gang involvement among delinquents in three Chinese cities. Adolescence, 42(166), 381-403.

Pereira, S. E. \& Sudbrack, M. F. (2008). Drogadição e atos infracionais na voz do adolescente em conflito com a Lei [Drug Addiction and Illegal Acts in the Voice of Adolescents in Conflict with the Law]. Psicologia: Teoria e Pesquisa, 24(2), 151-159. doi: 10.1590/S0102-37722008000200004

Selman, R. L. (1989). Fostering intimacy and autonomy. In W. Damon (Ed.), Child development today and tomorrow (1st. ed., pp. 409-435). San Francisco: Jossey-Bass Publishers.

Thornberry, T., Krohn, M., Lizotte, A. \& Chard-Wierschem, D. (1993). The role of juvenile gangs in facilitating delinquent behavior. Journal of Research in Crime and Delinquency, 30(1), 8-55. doi: 10.1177/0022427893030001005

Thornberry, T. P., Krohn, M. D., Lizotte, A. J., Smith, C. A. \& Tobin, K. (2003). Gangs and delinquency in developmental perspective. New York: Cambridge University Press.

Woodward, L. J., Fergusson, D. M. \& Horwood, L. J. (2002). Deviant partner involvement and offending risk in early adulthood. Journal of Child Psychology and Psychiatry, 43(2), 90-177. doi: 10.1111/1469-7610.00011 